\title{
A calcified mass
}

\author{
Ziba Mosayebi, ${ }^{1}$ Maryam Bahreini, ${ }^{1}$ Hadi Mirfazaelian, ${ }^{1}$ Yahya Daneshbod ${ }^{2}$
}

${ }^{1}$ Tehran University of Medical Sciences, Tehran, Iran ${ }^{2}$ Dr Daneshbod Path Lab, Shiraz, Iran

\section{Correspondence to} Dr Yahya Daneshbod, daneshbk@yahoo.com

Accepted 12 November 2015

\section{DESCRIPTION}

A 34-year-old woman presented to the emergency department, with a 1-year history of nonproductive cough and pleuritic chest pain. She had no upper respiratory tract symptoms, fever, sweating, radicular pain or weight loss. There was no abnormal finding on physical examination. Chest $\mathrm{X}$-ray showed a well-defined opacified area in the lower posterior lung field (figure 1A, B). CT imaging showed a round $3 \times 4 \mathrm{~cm}$ soft tissue mass in the posterior chest wall area, near the posterior mediastinum, within which multiple calcified components were identified. The mass had deformed the adjacent rib and there were no prominent lymph nodes present (figure 1C). On histological examination, classical schwannoma with extensive calcification was diagnosed (figure 1D). Immunohistochemistry for S100 was positive in the nucleus and cytoplasm confirmed the diagnosis.

Schwannoma (once termed neuroma or neurilemoma) is usually a benign slow-growing tumour of nerve sheath Schwann cells. It can involve any peripheral or cranial nerve containing Schwann cells and typically affects middle-aged women. Intercostal nerve schwannoma accounts for $<10 \%$ of primary chest neural tumours. While symptoms are usually caused by pressure on the surroundings, pain is infrequent and, if present, may be a symptom of malignancy.

The tumour may show degenerative changes (eg, calcification), which reflect the lesion's duration, especially in frequently traumatised locations. Calcified schwannomas often present as wellcircumscribed round or oval-shaped lesions. For the diagnosis, radiological evaluation is helpful,

\section{Learning points}

Schwannoma can involve any peripheral or cranial nerve containing Schwann cells.

- Calcified schwannomas often present as well-circumscribed round or oval-shaped lesions.

- For the diagnosis, radiological evaluation is helpful, although when it is not diagnostic, histological examination can be indicative.
To cite: Mosayebi Z, Bahreini M, Mirfazaelian $\mathrm{H}_{\text {, }}$ et al. BMJ Case Rep Published online: [please include Day Month Year] doi:10.1136/bcr-2015212675
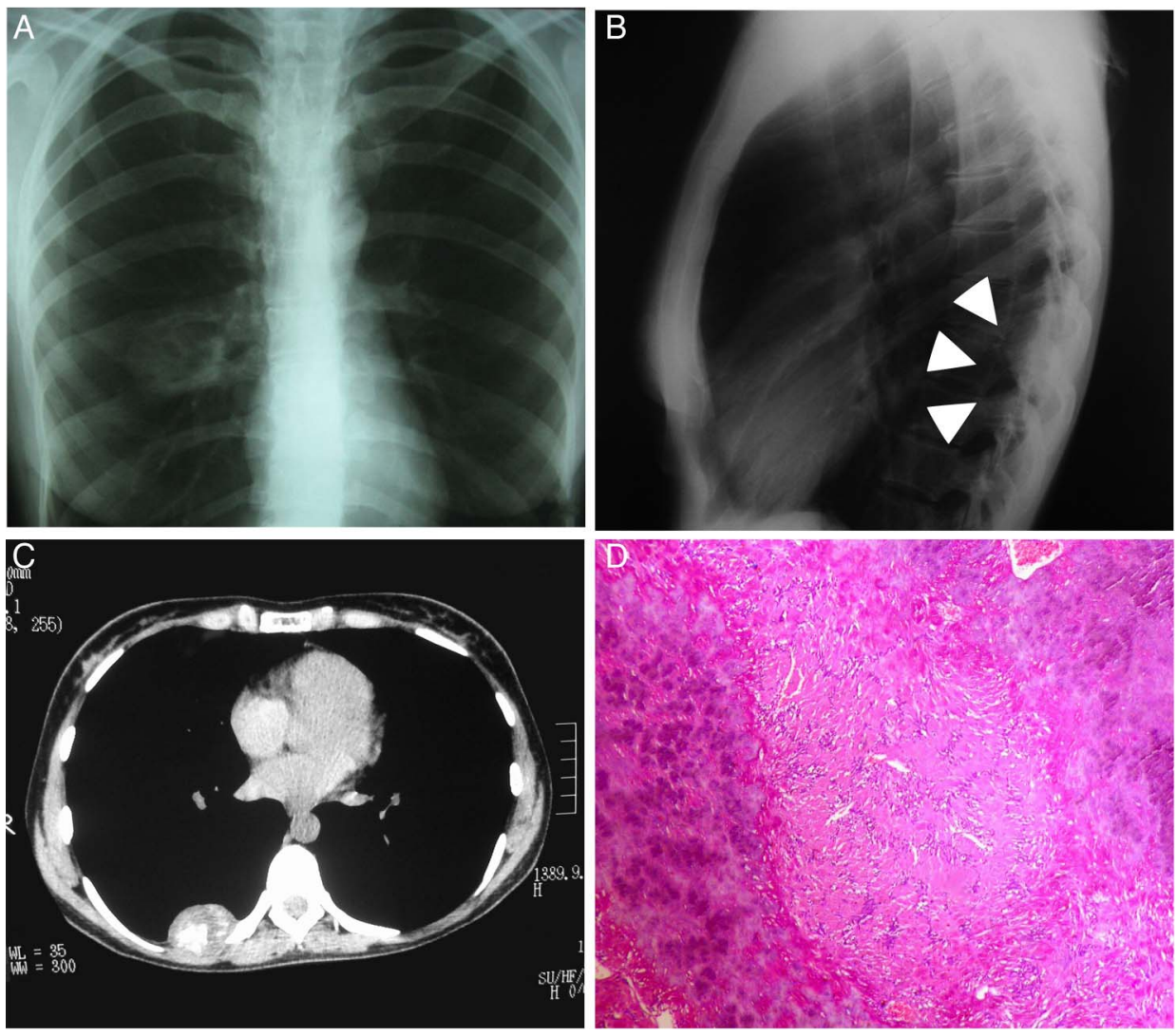

Figure 1 (A) Chest X-ray showing a well-defined round opacified mass in the lower posterior lung field noted in the posteroanterior and (B) lateral image. (C) Non-contrast chest CT scan exhibiting a soft tissue mass, $3 \times 4 \mathrm{~cm}$ in posterior chest wall area and near posterior mediastinum, with multiple foci of calcifications. (D) Histological examination showing schwannoma with extensive calcification. 


\section{Images in...}

although when it is not diagnostic, histological examination can be indicative. ${ }^{1}$ Treatment consists of surgical removal of the symptomatic or asymptomatic mass because of its subsequent growth. Calcification is in relation to the schwannoma's texture and blood supply, and can affect the outcome of surgical removal. ${ }^{2}$ Our patient refused surgical removal of the tumour and was lost to follow-up.

Contributors $\mathrm{ZM}$ and $\mathrm{MB}$ reviewed the literature and drafted the manuscript. HM and YD provided critical comments.
Competing interests None declared.

Patient consent Obtained.

Provenance and peer review Not commissioned; externally peer reviewed.

\section{REFERENCES}

1 Moroni AL, Righini C, Faure C, et al. CT Features of an unusual calcified schwannoma of the superior laryngeal nerve. AJNR Am J Neuroradiol 2007:28:981-2

2 Zhang Y, Yu J, Qu L, et al. Calcification of vestibular schwannoma: a case report and literature review. World J Surg Oncol 2012;10:207.

Copyright 2015 BMJ Publishing Group. All rights reserved. For permission to reuse any of this content visit http://group.bmj.com/group/rights-licensing/permissions.

BMJ Case Report Fellows may re-use this article for personal use and teaching without any further permission.

Become a Fellow of BMJ Case Reports today and you can:

- Submit as many cases as you like

- Enjoy fast sympathetic peer review and rapid publication of accepted articles

- Access all the published articles

- Re-use any of the published material for personal use and teaching without further permission

For information on Institutional Fellowships contact consortiasales@bmjgroup.com

Visit casereports.bmj.com for more articles like this and to become a Fellow 